\title{
Mortality
}

\section{in Crested Wheatgrass and Russian Wildrye}

\section{ALAST AIR McLEAN AND A. L. van RYSWYK}

Highlight: Mortality in crested wheatgrass and Russian wildrye near Kamloops, B.C., was observed in spring, 1970, and appeared to result from lower than average soil moisture reserves the previous season. Damage was heavy on a silt loam that graded to loamy fine sand at $50-\mathrm{cm}$ depth but was negligible on a uniform sandy loam overlying cobbly loamy sand. Field moisture levels below $25-\mathrm{cm}$ depth in the soil were greater on the sandy loam site than on the silt loam in spring, 1970. In that year, crested wheatgrass reached seed-set stage on the former, but inflorescences did not emerge from the boot on the latter site, where significant mortality occurred. No other published account of severe mortality of established stands of these grasses has been found.

Mortality in crested wheatgrass (Agropyron cristatum (L.) Gaertn. and $A$. desertorum (Fisch.) Schult.) and Russian wildrye (Elymus junceus Fisch.) is very unusual. Normally, crested wheatgrass is one of the most drought tolerant and cold resistant grasses we have for range seeding and is very grazing resistant. It is well adapted to the semiarid to subhumid rangelands of the Intermountain Region and Great Plains of the western USA and Canada. For example, Hull and Klomp (1966) report stands of crested wheatgrass in Idaho still vigorous as long as 30 years after seeding and withstanding annual precipitation as low as 5.49 inches. In southern Alberta Smoliak et al. (1967) report stands of crested wheatgrass vigorous and productive 38 years after seeding, including some of the driest years on record.

Authors are ecologist and soil specialist, Research Station, Canada Department of Agricult ure, Kamloops, B.C.

The study is Contribution No. 237 of the Research Station, Canada Department of Agriculture, Kamloops, B.C.

Manuscript received September 13, 1972.
Mortality does not appear to have been reported in the literature for either crested wheatgrass or Russian wildrye. Knowles (personal correspondence) has stated that he has seen it "on two occasions at Saskatoon, Saskatchewan, and in one case this was on very sandy soil following a dry fall." In connection with a grazing experiment in Utah, Frischknect and Harris (1968) observed that "the drought in 1956 caused break. ing up of some plant crowns" of crested wheatgrass. Springfield (1963) observed a similar phenomenon the same year in New Mexico, where he considered it to be a result of both drought and grazing. Sharp (1970) made a similar observation in southern Idaho after a drought year.

Mortality in the Kamloops area was first observed in a few stands of Fairway crested wheatgrass (Agropyron cristatum (L.) Gaertn.) after the winter of 1960-61.

At the Canada Agriculture Research Station, Kamloops mortality was recorded in 8-year-old stands of Summit crested wheatgrass (Agropyron desertorum (Fisch.) Schult.) and Sawki Russian wildrye after the winter of 1967-68.
Thirty and $45 \%$ mortality, respectively, were recorded for the two species. Similar mortality was observed on a nearly 20 year-old stand of Fairway crested wheatgrass. The summer and early fall of 1967 was dryer and hotter than usual. October rains, although light, caused the plants to grow late. A cold snap occurred in midDecember with little snow on the ground. The damage occurred only on stands growing on coarse-textured soils. At other locations in the area (e.g. Currie Field) crested wheatgrass seeded in 1938 is still vigorous and productive. All stands are grazed heavily in spring and fall each year. Damage, however, is rarely severe in the Kamloops area.

In spring, 1971, we observed many dead plants of crested wheatgrass on a date-of-clipping trial and in the fields of a grazing trial located at Mission Flats near Kamloops. The fields had been grazed during the spring of 1970 but not in fall because of the lack of regrowth. Mortality had occurred both on portions that were grazed and those that were ungrazed during 1970. Dead plants were not evenly scattered throughout the fields but tended to occur in patches. This paper attempts to explain this mortality in terms of precipitation and soil moisture regime, by comparison with a site (Curric) at which little mortality occurred.

\section{Methods and Materials}

All fields were point sampled for plant-cover estimates in early summer of 1970 and 1971. In the date-of-clipping 
trial the number of dead plants were recorded by treatment. Soil moisture (centered at the $5,10,25$, and $50 \mathrm{~cm}$ depths) was determined by the gravimetric method at Mission Flats and Currie Field (hereafter referred to as Mission and Currie) for the 2 years. Particle-size analysis (pipette method) was made and bulk density (core method) was determined on soil samples taken at the above depths from locations at Mission, showing severe and light mortality of crested wheatgrass, and from Currie. Field moisture was calculated in terms of depth of water using soil-moisture content (percent, weight basis) and bulkdensity values. It was not calculated for the 0 to $2.5-\mathrm{cm}$ layer as no field moisture data were available.

Mission site is on a flat, contemporary river terrace at about $380-\mathrm{m}$ elevation. Parent material is deep river alluvium, essentially stone free. Currie site is on a flat glacial gravel delta at about $520-\mathrm{m}$ elevation; its parent material is loess and alluvium over cobbly loamy sand beginning at about $100 \mathrm{~cm}$. Mission soil would be classed in the Gleysolic order and Currie in the Chernozemic order, Brown great group in the Canadian system (Canadian Soil Survey Committee, 1970). The two sites are about $15 \mathrm{~km}$ ( 8 miles) apart.

Sites of low mortality at Mission occurred in shallow depressions where soil textures would be expected to be slightly heavier.

\section{Results and Discussion}

Severe mortality, approaching 50\%, occurred in crested wheatgrass and Russian wildrye at Mission on both grazed
Table 1. Basal cover (\%) of living and dead plants of crested wheatgrass and Russian wildrye at Mission and Currie sites in spring 1970 and 1971.

\begin{tabular}{|c|c|c|c|c|c|c|}
\hline \multirow{3}{*}{$\begin{array}{l}\text { Year and } \\
\text { material }\end{array}$} & \multicolumn{4}{|c|}{ Crested whea tgrass } & \multirow{2}{*}{\multicolumn{2}{|c|}{$\begin{array}{l}\text { Wildrye } \\
\text { Mission }\end{array}$}} \\
\hline & \multicolumn{2}{|c|}{ Mission } & \multicolumn{2}{|c|}{ Currie } & & \\
\hline & Grazed & Ungrazed & Grazed & Ungrazed & Grazed & Ungrazed \\
\hline \multicolumn{7}{|l|}{1970} \\
\hline Live plants & 4.9 & 8.1 & - & - & 4.3 & 5.7 \\
\hline Dead plants & 0 & 0 & - & - & 0 & 0 \\
\hline \multicolumn{7}{|l|}{1971} \\
\hline Live plants & 2.4 & 5.1 & 4.1 & 5.1 & 2.3 & 3.8 \\
\hline Dead palnts & 2.5 & 2.1 & 0.5 & 0 & 2.3 & 2.3 \\
\hline Total & 4.9 & 7.2 & 4.6 & 5.1 & 4.6 & 6.1 \\
\hline
\end{tabular}

Table 2. Precipitation (water inches) for grazing season, Kamloops Airport.

\begin{tabular}{lccccc}
\hline \hline & \multirow{2}{*}{$\begin{array}{c}\text { Previous }^{1} \\
\text { Year }\end{array}$} & winter snow & March-May & June & \multicolumn{2}{c}{ Total } \\
\cline { 5 - 6 } 1966 & 4.17 & 1.46 & 0.99 & Dec-June & Jan-Dec \\
1967 & 4.04 & 1.47 & 0.09 & 6.62 & 11.90 \\
1968 & 2.92 & 2.32 & 0.68 & 5.60 & 9.36 \\
1969 & 4.63 & 2.76 & 2.00 & 5.92 & 9.93 \\
1970 & 2.00 & 1.04 & 1.00 & 9.39 & 14.21 \\
1971 & 4.53 & 1.53 & 1.42 & 7.04 & 7.68 \\
Average & 3.72 & 1.76 & 1.03 & 6.50 & 11.70 \\
\hline
\end{tabular}

${ }^{1}$ Includes, for example, for 1966, Dec. 1965 plus Jan, Feb. 1966 and is calculated by dividing depth of freshly fallen snow by 10 .

and ungrazed sites between spring, 1970, and spring, 1971, but not at Currie (Table 1). Precipitation recorded for Kamloops Airport, located midway between the two locations, was below average for the 1970 growing season (Table 2). Actual precipitation at each location should not vary much from that recorded at the airport. In a 3-year study van Ryswyk et al. (1966) show that April-to-October pre- cipitation varies little between 350 - and 520-m elevations at locations near those of the present study.

Field soil moisture, however, is quite different throughout the season at the two sites (Table 3). During the 1970 growing season (April to June), total moisture in the sampled layers was 2 to 3 $\mathrm{cm}$ less at Mission that it was at Currie even though on April 6 there was only

Table 3. Field soil moisture (cm water/depth class) at various depths (cm) and phenological stage of crested wheatgrass at Mission (severe mortality site) and Currie, 1970 and 1971.

\begin{tabular}{|c|c|c|c|c|c|c|c|c|c|c|c|c|c|}
\hline \multirow{3}{*}{$\begin{array}{l}\text { Location and } \\
\text { measurement }\end{array}$} & \multicolumn{9}{|c|}{1970} & \multicolumn{4}{|c|}{1971} \\
\hline & \multicolumn{2}{|c|}{ April } & \multicolumn{4}{|c|}{ May } & \multirow{2}{*}{$\frac{\text { June }}{30}$} & \multirow{2}{*}{$\frac{\text { July }}{28}$} & \multirow{2}{*}{$\frac{\text { Nov. }}{6}$} & \multirow{2}{*}{$\frac{\text { April }}{8}$} & \multirow{2}{*}{$\frac{\text { May }}{4}$} & \multirow{2}{*}{$\frac{\text { June }}{6}$} & \multirow{2}{*}{$\frac{\text { July }}{26}$} \\
\hline & 6 & 21 & 5 & 12 & 19 & 26 & & & & & & & \\
\hline \multicolumn{14}{|l|}{ Mission } \\
\hline \multicolumn{14}{|l|}{ Soil depth } \\
\hline $2.5-7.5$ & 0.98 & 0.34 & 0.24 & 0.21 & 0.18 & 0.17 & 0.33 & 0.14 & 0.61 & 0.75 & 0.15 & 0.32 & 0.13 \\
\hline $7.5-12.5$ & 0.96 & 0.40 & 0.35 & 0.27 & 0.28 & 0.22 & 0.22 & 0.13 & 0.52 & 0.74 & 0.30 & 0.28 & 0.16 \\
\hline $12.5-37.5$ & 4.16 & 2.24 & 2.16 & 1.46 & 1.40 & 1.08 & 1.19 & 0.70 & 0.95 & 1.84 & 1.24 & 0.95 & 0.76 \\
\hline $37.5-62.5$ & 1.41 & 1.08 & 1.11 & 1.05 & 1.05 & 0.99 & 0.78 & 0.69 & 0.84 & 1.05 & 1.02 & 0.93 & 0.81 \\
\hline Total & 7.51 & 4.06 & 3.86 & 2.99 & 2.91 & 2.46 & 2.52 & 1.66 & 2.92 & 4.38 & 2.71 & 2.48 & 1.86 \\
\hline Phenol. stage & - & - & $\begin{array}{l}\text { early } \\
\text { boot }\end{array}$ & $\begin{array}{l}\text { full } \\
\text { boot }\end{array}$ & - & no furthe & evelopm & & & - & $\begin{array}{l}\text { full } \\
\text { boot }\end{array}$ & $\begin{array}{l}\text { early } \\
\text { flower }\end{array}$ & $\begin{array}{l}\text { seed } \\
\text { ripe }\end{array}$ \\
\hline \multicolumn{14}{|l|}{ Currie } \\
\hline \multicolumn{14}{|l|}{ Soil depth } \\
\hline $2.5-7.5$ & 0.83 & 0.52 & 0.33 & 0.28 & 0.25 & 0.25 & 0.37 & 0.22 & 0.53 & 0.91 & 0.36 & 0.97 & 0.21 \\
\hline $7.5-12.5$ & 0.84 & 0.66 & 0.50 & 0.43 & 0.48 & 0.37 & 0.31 & 0.22 & 0.45 & 0.92 & 0.52 & 0.50 & 0.32 \\
\hline $12.5-37.5$ & 4.34 & 4.10 & 2.98 & 3.36 & 2.66 & 2.45 & 2.35 & 1.89 & 2.00 & 4.94 & 3.22 & 2.73 & 2.24 \\
\hline $37.5-62.5$ & 3.70 & 3.84 & 2.97 & 2.68 & 2.72 & 2.50 & 1.46 & 1.70 & 1.99 & 4.21 & 2.90 & 2.54 & 1.70 \\
\hline Total & 9.71 & 9.12 & 6.78 & 6.75 & 6.11 & 5.57 & 4.49 & 4.03 & 4.97 & 10.98 & 7.00 & 6.74 & 4.47 \\
\hline Phenol. stage & - & - & $\begin{array}{l}\text { early } \\
\text { boot }\end{array}$ & $\begin{array}{l}\text { full } \\
\text { boot }\end{array}$ & $\begin{array}{l}\text { early } \\
\text { head }\end{array}$ & $\begin{array}{l}\text { full } \\
\text { head }\end{array}$ & dough & $\begin{array}{l}\text { seed } \\
\text { ripe }\end{array}$ & - & - & $\begin{array}{l}\text { early } \\
\text { boot }\end{array}$ & $\begin{array}{l}\text { early } \\
\text { flower }\end{array}$ & $\begin{array}{l}\text { seed } \\
\text { ripe }\end{array}$ \\
\hline
\end{tabular}


Table 4. Soil texture (\%), textural class, and bulk density $\left(\mathrm{g} / \mathrm{cm}^{3}\right)$ at various soil depths and number for Mission (severe and light mortality locations) and Currie sites.

\begin{tabular}{|c|c|c|c|c|c|c|c|c|c|c|c|}
\hline \multirow[b]{3}{*}{ Item } & \multicolumn{3}{|c|}{ Clay } & \multicolumn{3}{|c|}{ Sand } & \multicolumn{3}{|c|}{ Textural class ${ }^{1}$} & \multicolumn{2}{|c|}{ Bulk density } \\
\hline & \multicolumn{2}{|c|}{ Mission } & \multirow[t]{2}{*}{ Currie } & \multicolumn{2}{|c|}{ Mission } & \multirow[t]{2}{*}{ Currie } & \multicolumn{2}{|c|}{ Mission } & \multirow[t]{2}{*}{ Currie } & \multirow{2}{*}{$\begin{array}{l}\text { Mission } \\
\text { (Severe) }\end{array}$} & \multirow[t]{2}{*}{ Currie } \\
\hline & Severe & Light & & Severe & Light & & Severe & Light & & & \\
\hline \multicolumn{12}{|c|}{ Soil depth sampled $(\mathrm{cm})$} \\
\hline $0-2.5$ & - & - & - & - & - & - & - & - & - & $0.92 d^{2}$ & $1.12 \mathrm{~b}$ \\
\hline $4-6.5$ & 20 & 22 & 14 & 20 & 12 & 51 & sil & sil & l-sl & $1.01 \mathrm{bc}$ & $1.15 \mathrm{~b}$ \\
\hline $8-12$ & 19 & 21 & 14 & 22 & 10 & 49 & sil & sil & l-sl & $0.95 \mathrm{~cd}$ & $1.31 \mathrm{~b}$ \\
\hline $21-29$ & 14 & 19 & 13 & 35 & 9 & 56 & sil-1 & sil & sl-1 & $1.08 \mathrm{~b}$ & $1.40 \mathrm{a}$ \\
\hline $46-54$ & 7 & 9 & 10 & 74 & 67 & 60 & fsl-lfs & fsl & sl & $1.20 \mathrm{a}$ & $1.45 \mathrm{a}$ \\
\hline \multicolumn{12}{|c|}{ Number of dead } \\
\hline plants & many & few & none & many & few & none & many & few & none & many & none \\
\hline
\end{tabular}

${ }^{1}$ Designations are: sil = silt loam; $1=$ loam; sl = sandy loam; fsl = fine sandy loam; and lfs = loamy fine sand according to U.S. Dept. Agr. Soil Survey Manual Handbook No. 18, 1951.

${ }^{2}$ Values in a column followed by different letters are significantly different at $P \geqslant 0.05$ by Duncan's Multiple Range test.

$0.4 \mathrm{~cm}$ less at the former. Similar trends are evident for 1971. Phenological development of crested wheatgrass was arrested in early May, 1970, (Table 3) at Mission, indicating that moisture available to the plants had been depleted. It is likely that plant mortality began at this time and was completed by July, when soil moisture was the lowest recorded for the two seasons.

In 1971, however, soil moisture for Mission in the early part of the season was lower than in 1970; plants were about 1 week advanced (full boot, May 4, 1971, vs May 12, 1970). By the end of July soil moisture was slightly higher in 1971 than 1970 . This would indicate that potential evapotranspiration during April to July, inclusive, was less in 1971 than in 1970 , so that the drought threshold was not reached in 1971. It is substantiated by completion of the phenological cycle in 1971 and the survival of most plants in that year.

Soil-moisture regime within the profile, as well as total water-content, is quite different for the two soils. Currie retains considerably more moisture in the lower layers throughout the season than does Mission. Differing textural characteristics (Table 4) may explain the differing moisture regimes of the two soils. Mission soil has considerably heavier texture in its surface than its subsoil, silt loam grading to loamy fine sand, whereas Currie has a more nearly uniform sandy loam texture throughout the sampled layers that overlie cobbly loamy sand.

Heavy-textured soils generally have higher water-holding capacities than do lighter ones, so that the surface layers of Mission would hold more water than the lower ones. On Currie, soil moisture would be distributed more uniformly throughout the sampled layers. Because of this difference in moisture distribution, water loss due to evaporation from the surface layers would be greater at Mission than at Currie. The greater moisture stored in lower layers at Currie would tend to be retained because it must move up through the profile by capillarity. This movement would become very slow as it moved through surface layers that were already dry. Any upward moisture movement, then, would likely be in the vapour phase.

A further explanation may be found in the observation that the Currie soil is underlain by very coarse material. This would allow soil-moisture levels in the overlying layers to build up to high levels and moisture tension to reach low values before water would be drained out by the coarse pores of the underlying material, which could fill only at low tensions. The finer underlying material of the Mission soil, on the other hand, would be capable of draining its overlying material at higher tensions. Thus when snow melt occurs, supplying the soil with a large amount of water in a short time, it is possible that Currie soil could retain more of this water than could Mission.

The low mortality site at Mission has slightly heavier texture, and so should have higher water-holding capacities than the high mortality site. Drought conditions at Mission must have fluctuated about a critical point for slight textural differences to have resulted in mortality.

If soil-moisture tension could be measured in situ throughout the season, a better understanding of plant mortality might be obtained because tension would be more closely related to plant response and not be complicated by hysteresis effects as is soil-moisture content. This could give a value for the threshold limit, in terms of soil-moisture tension, at which mortality occurs during the critical stage of plant growth when inflorescence is developing.

The available data indicate that mortality in the 1970-71 period appears to be due to extreme drought during a critical phenological stage in crested wheatgrass growth. This was likely the stage of inflorescence development. Damage could have also occurred at some other stage but there is no definite evidence to indicate this. Other observed incidents of mortality may have occurred under different circumstances.

\section{Literature Cited}

Canadian Soil Survey Committee. 1970. The system of soil classification for Canada. Queen's Printer, Ottawa.

Frischknect, N. C., and L. E. Harris. 1968. Grazing intensities and systems on crested wheatgrass in central Utah: response of vegetation and cattle. U. S. Dep. Agr. Tech. Bull. 1388.47 p.

Hull, A. C., Jr., and G. J. Klomp. 1966. Longevity of crested wheatgrass in the sagebrush-grass type in southern Idaho. J. Range Manage. 19:5-11.

Sharp, L. A. 1970. Suggested management programs for grazing crested wheatgrass. U. of Idaho Forest, Wildlife, and Range Exp. Sta. Bull. 4.19 p.

Smoliak, S., A. Johnston, and L. E. Lutwick. 1967. Productivity and durability of crested wheatgrass in southeastern Alberta. Can. J. Plant Sci. 47:539-548.

Springfield, H. W. 1963. Cattle gains and plant responses from spring grazing on crested wheatgrass in northern New Mexico, U. S. Dep. Agr. Prod. Res. Rep. 74. 45 p.

van Ryswyk, A. L., Alastair McLean, and L.S. Marchand. 1966. The climate, native vegetation, and soils of some grasslands at different elevations in British Columbia. Can. J. Plant Sci. 46:35-50. 